\title{
Kamu Hastanelerinde Analitik Ăg Süreci Yöntemi ile Finans Yöneticisi Seçimi
}

\author{
Nesrin AKÇA*, Seda SÖNMEZ**, Şeyda GÜR ${ }^{* * *}$, Ali YILMAZ****, Tamer EREN***** \\ ÖZ
}

Hastane işletmelerinin büyük çoğunluğunun kamu sahipliğinde bulunması ve yönetim teknolojilerinin kamu düzenlemeleriyle yönlendirilmesi, hastane işletmelerinin gerek genel yönetim gerekse finans yapısının profesyonel yönetim özelliklerine uymasını zorunlu kılmaktadır. Türkiye şartlarına bakıldığında; finans yöneticiliği gibi önemli bir pozisyonun çoğunlukla hekim yöneticilerce üstlenildiği görülmektedir. Kamu hastanelerinde, herhangi bir unvan ile finans yöneticisi pozisyonunda ya da bu departmanlarda çalışanların finans konusundaki yeterliliklerini ya da bilgi düzeylerini belirlerken hangi kriterlerin etkili olup olmadığının belirlenmesi amacıyla karar verme sürecinde yaşanabilecek zorlukların üstesinden gelmede yardımcı olan çok ölçütlü karar verme yöntemleri ön plana çıkmaktadır. Bu çalışmada kamu hastanelerinde finansal yönetici seçimini etkileyen faktörler belirlenerek çok ölçütlü karar verme yöntemlerinden Analitik Ă̆ Süreci (AAS) yöntemi ile ağırlıkları hesaplanmıştır. Kırıkkale'de bir kamu hastanesinde yapılan uygulama ile aday kişiler arasından seçim yapılmıştır. Çalışmadan elde edilen sonuçlara göre; en güçlü aday $\% 53$ 'lük önem derecesiyle mali hizmetler başkanı olurken, onu \%22'lik önem derecesiyle döner sermaye saymanı izlemektedir.

Anahtar Kelimeler: Analitik A ̆g Süreci, Personel Seçimi, Finansal Yönetici, Kamu Hastaneleri

JEL Sinıflandırması: C44, M12

\section{Financial Manager Selection with Analytic Network Process Method in Public Hospitals \\ ABSTRACT}

The fact that the vast majority of hospital enterprises are publicly owned, and that management technology is guided by public regulations obliges that hospitals conform to the professional management characteristics of both the general management and the financial structure. Considering to conditions in Turkey, it is seen that an important position as finance director is undertaken mostly by physician's managers. In public hospitals, it is important to know which criteria are in effect when measuring the qualifications or levels of knowledge of financial managers, or employees. While determining this, multi-criteria decision-making methods are helping to overcome the difficulties that may arise in the decision-making process. In this study, it was determined factors affecting the selection of financial managers in public hospitals. Then, the weights of these factors were calculated by the Analytical Network Process (ANP) method, which is a multi-criteria decision method. The application was made in a public hospital in Kurkkkale and the candidates were selected. According to the results obtained by working; the strongest candidate is the head of financial services with a share of $33 \%$, followed by the treasurer of circulating capital with an equity of $25 \%$.

Keywords: Analytic Network Process, Personnel Selection, Financial Administrator, Public Hospitals

JEL Classification: C44, M12

Geliş Tarihi / Received: 05.02.2018 Kabul Tarihi /Accepted: 18.04.2018

\footnotetext{
* Dr. Öğr. Üyesi, Kırıkkale Üniversitesi, Sağlık Bilimleri Fakültesi, Sağlık Yönetimi Bölümü, nakca@kku.edu.tr, ORCID: 00000001-5546-1443

** Arş. Gör., Kırıkkale Üniversitesi, Sağlık Bilimleri Fakültesi, Sağlık Yönetimi Bölümü, sedakaya117@gmail.com, ORCID: 00000002-8773-6007

**** Yüksek Lisans Öğrencisi, Kırıkkale Üniversitesi, Mühendislik Fakültesi, Endüstri Mühendisliği Bölümü, seydaaa.gur@gmail.com, ORCID:0000-0002-4639-9657

**** Dr. Öğr. Üyesi, Kırıkkale Üniversitesi, Sağlık Bilimleri Fakültesi, Sağlık Yönetimi Bölümü, aliyilmaz69@gmail.com, ORCID:0000-0002-7482-1712

****** Doç. Dr., Kırıkkale Üniversitesi, Mühendislik Fakültesi, Endüstri Mühendisliği Bölümü, tamereren@gmail.com, ORCID: 0000-0001-5282-3138
} 


\section{GİRIŞ}

Finansman fonksiyonu; sağlık işletmelerinin sağlık hizmeti üretmek için ihtiyacı olan fonları, uygun şartlarla tedarik etmek ve tedarik edilen bu fonları işletmenin elinde var olan fonlar ile beraber işletmenin firma değerini artırmak için verimli, etkili ve ekonomik kullanımı ile ilgili karar ve işlemlerden oluşan fonksiyondur. Finans fonksiyonunun yerine getirilmesi ile ilgili olarak alınan kararların işletmenin genel amacına ulaşmak için son derece önemli kararlar olduğu bilinmektedir. Gerçekten de iyi bir finansal planlamanın yapılamaması, yapılan finansal planların iyi uygulanamaması ya da uygulama sonuçlarının gereği gibi değerlendirilememesi işletmelerin başarısızlık nedenleri arasında önemli bir yer tutmaktadır (Akar, 2002:2-3; Ağırbaş, 2014:18).

Finansman fonksiyonu hastane işletmeleri açısından son derece önemlidir. $\mathrm{Bu}$ fonksiyondan, hastanenin var olan diğer fonksiyonları da etkilenmekte ve hastanenin ayakta kalmasında, sağlık hizmeti üretmesinde, istediği yatırımı gerçekleştirebilmesinde, kaynak tahsisi ve stratejik planlama $v b$. yönetim fonksiyonlarının sürdürülmesinde izleyeceği finansal politikaların önemi yadsınamayacak derecede büyüktür (Akar vd., 2005:344).

Finanstan sorumlu yöneticiler; finans fonksiyonunu en iyi biçimde gerçekleştirebilmek için ilişki içinde oldukları finansal sistemin işleyişini ve yapısını çok iyi bilmek zorundadır. Finans yöneticisinin firma değerini maksimize edebilmesi için; planlama, varlıkların (aktiflerin) ve kaynakların (pasiflerin) yönetimi olmak üzere üç fonksiyonu başarılı bir şekilde yerine getirmesi gerekmektedir. Finanstan sorumlu yöneticinin görevleri, finansal yönetimin önemi ve fonksiyonlarının anlaşılmasına yardımcı olmaktadır (Ağırbaş, 2014:29).

Sağlık kurumlarında finansal yönetim pozisyonlarında çalışan finansal yöneticilerin, finansal görevleri yapabilmeleri ile ilgili sahip olması gereken nitelikler ile bu görevleri yerine getirmedeki etkililik düzeylerinin bir arada olması finansal yönetici yeterliliğini ifade etmektedir (Akar vd., 2003). Finansal yöneticilerin görevlerini en iyi biçimde yapabilmeleri için finansal planlama, finansal organizasyon, finansal yürütme, finansal analiz ve denetim konularında bilgi sahibi olması gerekmektedir. Bu konularda yeterli donanıma sahip olan kişiler arasından en uygun olanını finansal yönetici pozisyonunda görevlendirmek doğru bir seçim olacaktır. Bu noktada devreye giren çok ölçütlü karar verme yöntemleri karar verme süreçlerinde etkili olan faktörlere göre modelleme ve analiz etmeyi, aynı zamanda seçim yapılacak alternatifler arasında en uygun olanı, belirlenen hedefleri en iyi yansıtanı bulmaya olanak sağlar. Bu çalışmada finansal yönetici seçimi için gerekli olan kriterler belirlenmiş ve finansal yöneticilerde aranan özelliklere göre değerlendirilen adayların önem dereceleri hesaplanmıştır. Sağlık sektöründe verimli ve etkin hizmet verilebilmesi, organizasyonların amaçlarına yönelik planlı hareket edecek kişilerin seçilebilmesi niteliksel ve niceliksel faktörlerin birlikte değerlendirilmesi ile yapılmaktadır.

Kamu sahipliğindeki kurumlarda, finansal yönetimin temel amacı; hastane işletmelerinin firma değerini etkililik ve verimlilik koşulları altında maksimize etmek, işletmenin gerçek sahibi olan devletin giderlerini minimize etmek ve kaynakların etkili kullanımını sağlamaktır (Akar, 2002:6). Finansal yönetici finansal planlama yaparken hastanenin gelecekteki pozisyonunu koruyup geliştirecek, firma değerini artıracak ve şekillendirecek planlar yapmalıdır (Özgülbaş, 2002:64).

Diğer işletmelerde olduğu gibi sağlık işletmelerinde de finansal yönetimin rolü; var olan kaynakları en verimli ve en etkili biçimde kullanarak işletmenin piyasa değerini maksimum seviyeye çıkarmaktır (Gapenski, 2007: 6).

Finansal yöneticilerin görevlerini başarılı bir şekilde yerine getirebilmesi için üç ayrı kademede bilimsel disiplin ile ilişki içerisinde olmaları gerekir. Birincil disiplinler, muhasebe, mikro ekonomi ve makro ekonomi olarak sıralanırken; kantitatif teknikler, pazarlama ve üretim 
yönetimi ikincil disiplin olarak; hukuk (mevzuat) ve davranış bilimleri de üçüncül disiplinler olarak sıralanabilir. Belirtilen bu disiplinler finansal yöneticilerin sahip olması gereken asgari temel bilgileri ifade etmekte olup, genel olarak sağlık işletmesi/işletme altyapılı programlarla edinilen bilimsel disiplinleri tanımlamaktadır. Finansal yöneticiler, faaliyetleri esnasında bu disiplinlerin tekniklerini kullanmak ya da bu disiplinlerde çalışan kişilerle birlikte çalışmak durumundadırlar. $\mathrm{Bu}$ nedenle her üç basamaktaki disiplinleri çok iyi derecede bilmek gerekmektedir (Ağırbaş, 2014:31; Akar vd., 2005:335). Çok ölçütlü karar verme yöntemleri değerlendirilmesi gereken seçenekler kümesi içerisinde hangi ölçütler kullanılarak değerlendirme yapılacağına ve nasıl değerlendirme yapılacağına yardımcı olmaktadır. Bu ölçütlerin birbirlerine göre önem dereceleri nedir ve seçenekleri nasıl etkilemektedir bunun bilgisini vermektedir. Çok ölçütlü karar verme yöntemlerinden olan Analitik Ağ Süreci yöntemi ise söz konusu problemi ele alırken hem nicel hem de niteliksel verileri bir arada değerlendirmeye olanak sağlar. Belirlenen ölçütler arasındaki etkileşimleri ve ilişkileri dikkate alır ve bu etkileşimlerin seçenek kümesi üzerindeki etkisini ağ yapısı ve geri bildirimler sayesinde inceler.

Çalışmanın ilk bölümü giriş kısmı olup, ikinci bölümünde literatür taramasında yapılan çalışmalar hakkında bilgilere yer verilmiştir. Üçüncü bölümde ise çalışmada kullanılan Analitik Ağ Süreci yöntemi anlatılmıştır. Dördüncü bölümde çalışmanın veri seti ile ilgili bilgi verilerek araştırmadan bahsedilmiştir. Son bölümde ise çalışmanın genel sonuçlarına yer verilmişstir.

\section{LITERATÜR TARAMASI}

Personel seçim problemi günümüzde özel veya kamu işletmelerinde önemi giderek artan bir konu haline gelmektedir. Yapılan doğru seçimin her alanda etkisini görmek personellerin seçimi konusunda verilen kararları giderek zorlaştırmaktadır. Bu bölümde literatürdeki personel seçim problemi ile ilgili yapılan çeşitli çalışmalar incelenmiştir ve bu çalışmalara bakıldığında sonuç olarak ulaşılmak istenen amaçlar birbirlerine benzerlik göstermektedir. Temelde ele aldıkları sahalara, işletmelere veya kullandıkları yöntemler ile farklılıklarını ön plana çıkarmışlardır. Buna göre Lin (2010) AAS ve Veri Zarflama Analizleri (VZA) ile yönetim departmanında, Kelemenis ve Askounis (2010) bulanık TOPSIS yöntemi ile üst düzey yönetici seçimi yapmışlardır. Akhlaghi (2011) geliştirdikleri uzman sistem ile, Mojahed vd. (2013) AHP ve ELECTRE yöntemlerinin entegre hali ile, Kabak (2013) Dematel ve bulanık AAS yöntemleri ile, Saad vd. (2013) bulanık yöntemler ile personel seçimi problemini ele almışlardır. Çeşitli sektörlerde personel seçimi için Chaghooshi vd. (2014) AHP yöntemini, Koyuncu ve Özcan (2014) karşılaştırmalı olacak şekilde AHP ve TOPSIS yöntemlerini, Zolfani ve Banihashemi (2014) belirlenen kriterleri ağırlıklandırmak için çok ölçütlü karar verme yöntemlerini, bu ağırlıkları değerlendirmek için oyun teorisini, Bedir ve Eren (2015) AHP ve PROMETHEE yöntemlerini, Chang vd. (2015) entegre halinde AASTOPSIS-Bulanık Delphi yöntemlerini, Yıldız ve Aksoy (2015) AHP; Akar ve Çakır (2016) AHPMOORA; Chen vd. (2016) TOPSIS-PROMETHEE; Özder vd. (2016) AAS-TOPSIS; İçigen ve Çetin (2017) AHP-TOPSIS; Kenger (2017) Gri İlişkisel Analiz (GİA) ve Ulutaş vd. (2018) bulanık AHPGİA çok ölçütlü karar verme yöntemlerini kullanmışlardır.

Çalışmada kullanılan AAS yöntemi ile ilgili literatürde farklı alanlarda yapılmış incelemeler mevcuttur. $\mathrm{Bu}$ bölümde yapılan çalışmalar ile ilgili kısaca bilgi verilerek konu olarak uygulama yapılan alanlar hakkında bilgi edinilmesi amaçlanmıştır. Sadece AAS ile ilgili olan çalışmalar şunlardır; Meade ve Presley (2002) AR-GE projelerinin seçiminde AAS yöntemini, Cheng vd. (2005) bir alışveriş merkezi için en uygun yer seçiminde AAS yöntemini, Özbek ve Eren (2013) 3PL lojistik firma seçiminde AAS yöntemini kullanmıştır.

AAS ile bütünleşik olan çalışmalar ise şunlardır; Görgülü vd. (2013) optimal yatırım stratejilerinin seçiminde AAS ve TOPSIS yöntemlerini, Özder vd. (2016) muhasebe paket programı seçiminde AAS ve TOPSIS yönteminin entegre halini, Hamurcu vd. (2016) proje 
seçim probleminde AAS ve 0-1 Hedef programlama yöntemlerini kullanmışlardır. Özcan vd. (2017) AAS ve PROMETHEE entegrasyonu ile CSP teknolojisine sahip güneş enerjisi santrallarının seçimini yapmıştır. Gür vd. (2017) AAS ve PROMETHEE yöntemlerini gıda sektöründe pazarlama stratejisi seçimi için kullanmışlardır.

Yapılan literatür taramaları sonucunda; sağlık kurumlarında finansal yönetim ile ilgili olarak AAS yöntemine rastlanmamıştır. Bu nedenle bu çalışma özgün bir çalışma özelliği taşımaktadır.

\section{YÖNTEM}

\subsection{Analitik Ăg Süreci Yöntemi}

Saaty (1996) tarafından geliştirilen AAS yönteminde, karar verme problemleri için faktörler arasında modelleme yaparken şebeke yapısı kullanılmaktadır. Faktörler arasındaki bağımlılıkları dikkate almaktadır ve bu bağımlılıklardan oluşan etkileşimleri kullanmaktadır. $\mathrm{Bu}$ etkileşimler ve bağımlılıklar yöntemin odak noktasıdır.

AAS yöntemi bu yapısı ile karar problemlerinde daha gerçekçi bir yaklaşım sunmaktadır ve problemin daha iyi analiz edilmesini sağlamaktadır (Pamukçu, 2014). AAS yöntemi temel olarak 5 adımdan oluşmaktadır.

Adım 1. Problemin Tanımlanması ve Şebeke Yapısının Oluşturulması: Ele alınan problemin yapısı detaylı bir şekilde analiz edilerek seçeneklerin açıkça belirgin hale getirildiği ve bu seçeneklerin değerlendirileceği kriterlerin belirlendiği aşamadır. Sistemi çeşitli bileşenlere ayırarak karar probleminin şebeke yapısı oluşturulur.

Adım 2. Faktörler Arasındaki İlişkilerin Kurulması: Bileşenlerine ayrılan problemin yapısını tam olarak ifade edebilmek için faktörler arasındaki tüm karşılıklı etkileşimlerin dikkate alındığı aşamadır. Geri beslemelerden ve bağımlılıklardan oluşan bu yapıda kriterlerin özellikleri ön plana çıkartılarak hiyerarşik yapıdan ayrılır.

Adım 3. İkili Karşılaştırma Matrislerinin Oluşturulması: Konuyla ilgili uzmanların ele alınan problemde belirlenen faktörleri değerlendirdiği aşamadır. Faktörlerin karşılaştırması yapılarak birbirlerine göre üstünlükler belirlenir. Bu karşılaştırmalarda Tablo 1'de verilen Saaty (1990)'nin 1-9 skalası kullanılmaktadır.

Tablo 1: Önem Dereceleri

\begin{tabular}{|c|l|l|}
\hline Önem Derecesi & Tanım & Açıklama \\
\hline 1 & Eş önem & Hedefe eşit derecede etkide bulunurlar \\
\hline 2 & Zayıf önem & Tecrübe ve yargıya göre biri diğerinden zayıf derecede üstün \\
\hline 3 & Orta derece önem & Tecrübe ve yargıya göre biri diğerinden orta derecede üstün \\
\hline 4 & Orta üstü önem & Tecrübe ve yargıya göre biri diğerinden orta üstü derecede üstün \\
\hline 5 & Güçlü önem & Tecrübe ve yargıya göre biri diğerinden güçlü derecede üstün \\
\hline 6 & Güçlü üstü önem & Biri diğerine göre güçlü üstü derecede üstün \\
\hline 7 & Çok güçlü önem & Biri diğerine göre çok daha güçlü derecede üstün \\
\hline 8 & Çok çok önem & Biri diğerine göre çok çok güçlü derecede üstün \\
\hline 9 & Aşırı önem & Birinin diğerine göre bariz üstünlüğü kanıtlanmış \\
\hline Eğer, bir kriter diğer kritere göre daha az önemli ise, yukarıdaki derecelerin 1/derece yazılır. \\
\cline { 1 - 2 }
\end{tabular}

(Kaynak: Saaty, T. L. (1990). How to make a decision: the analytic hierarchy process. European journal of operational research, 48(1), 9-26.) 
Yapılan ikili karşılaştırmalarda uzman sayısı arttı̆̆ında, matrisleri uzlaşma yoluyla veya yapılan karşılaştırmaların geometrik ortalaması alınarak oluşturulmaktadır. Tablo 1'deki önem dereceleri kullanılarak ilişkili olan iki kriter değerlendirilebilmektedir. Karar vericilerin fikirleri altında değerlendirmeleri yapılan kriterlerden elde edilen matrisler Süpermatrislerin oluşturulmasında kullanılmaktadır.

Adım 4. Süpermatrislerin Oluşturulması: Model yapısında bulunan kriterler arasındaki bağımlılıkların aktarıldığı süpermatris parçalı bir yapıdadır. Önceliklerin elde edilmesinde yardımcı olan bu yapılar ikili karşılaştırma matrislerden elde edilen değerlerden oluşmaktadır. Hücrelere yerleştirilen bu değerler kaç tane kriter/alt kriter var ise o sayıda olmaktadır ve süpermatrisin boyutunu belirlemektedir. Ağırlıklandırılmamış, ağırlıklandırılmış ve limit süpermatris başlıkları altında toplanan süpermatris yapısında; ağırlıklandırılmamış süpermatris yakınsamadan önce elde edilen matristir ve kararlı bir yapıya sahip değildir. Matris yapısı stokastik hale getirilmesi için normalizasyon işlemleri sütun toplamları 1'e eşitleninceye kadar yapılır ve elde edilen önceliklerin bir noktada toplanması için süper matrisin $2 n+1$ dereceden kuvveti alınır. Bu işlem matris içerisindeki tüm değerler aynı olana kadar devam ettirilir. Sonuç olarak elde edilen bu matrise limit süpermatris denilmektedir.

Adım 5. En Iyi Alternatifin Seçilmesi: Elde edilen limit matris ile alternatiflere ait önem dereceleri hesaplanmış olur. Bu matriste en yüksek değere sahip olan alternatif en iyi alternatif olarak değerlendirilmektedir (Şah,2010).

\section{VERI SETİ ve ARAŞTIRMA}

Sağlık kurumlarında hizmetin etkin ve verimli bir şekilde sağlanabilmesi için görev yapacak personellerin seçiminde çok çeşitli faktörler dikkate alınmaktadır. Organizasyonların temel olarak belirledikleri amaçlara uygun olan, profesyonel olarak çalışacak kişilerin açılan pozisyonlara alınma süreci karar verme aşamasında stratejik bir öneme sahiptir. Bu çalışmada bir kamu hastanesi için finansal yönetici seçim problemi ele alınmıştır. Belirlenen kriterlere göre 5 aday çok ölçütlü karar verme yöntemlerinden AAS yöntemi ile değerlendirilmiş̧tir. AAS yöntemi faktörler arasındaki bağımlılıkları ve etkileşimleri dikkate alan geri beslemeli bir ağ yapıs1 olan karar verme süreçlerinde etkili bir yöntemdir. Yapılan bu uygulamada yöneticilerde olması gereken özellikler belirlenerek 9 kriter oluşturulmuştur. Eğitim, deneyim, iletişim becerisi, internet sitesi izleme, mevzuat takibi, periyodik yayin takibi, bilgisayar ilgisi, finansal bilgi sistemi, muhasebe otomasyon programı olmak üzere 9 kriter belirlenmiştir (Berger, 2008; Honoré ve Costich, 2009). Sahadaki uygulayıcılardan olan hastanede finansal yöneticilerin ve sağlık alanında akademik uzmanların görüşlerine başvurularak bu kriterler belirlenmiştir. $\mathrm{Bu}$ kriterler literatürde de araştırılarak çalışma desteklenmiştir. Oluşturulan kriterler arasında birbirleri ile ilişkiler ve hangi kriter niteliksel olarak diğer kriteri veya kriterleri etkiliyor şeklinde temelde etkileşim ve bağımlılığa dayanan ağ yapısı modellenmiştir. Örneğin deneyim ve eğitim kriterleri birbirlerini etkilerken mevzuat ve periyodik yayın takibi kriterleri de birbirlerini etkilemektedir. Bu kriterlerin birbirini etkilemesi, yapılacak olan seçimde bir kriter aranırken aynı zamanda bahsedilen diğer kriterle de ilişki içerisinde olduğunu birbirlerini tamamladıklarını göstermektedir. Diğer kriterler arasındaki benzer ilişkilerde kurularak modele aktarılmıştır. Çalışmanın uygulama adımları Şekil 1'de verilmektedir.

Çalışmada kullanılan yöntemin adımlarına göre;

Problemin tanımlanması; stratejik bir öneme sahip olan finansal yönetici seçim problemi ele alınarak kamu hastanelerinde etkin ve verimli bir hizmet verilebilmesi için yöneticilerde aranan özelliklere göre kriterler belirlenmiştir. Sahadaki uygulayıcılardan olan hastanede finansal yöneticilerin ve sağlık alanında akademik uzmanların görüşlerine başvurularak bu kriterler belirlenmiştir. 6 uzman görüşü geometrik ortalama ile birleştirilmiştir. 
A $\breve{g}$ yapısının oluşturulmasl; finansal yönetici seçim problemi için ele alınan toplamda 9 tane kriter 3 ana başlık altında toplanarak AAS yönteminde kullanılmak üzere aralarındaki etkileşimler ve bağımlılıklar belirlenmiş ve ağ yapısı oluşturulmuştur.

Çalışmada kullanılacak olan kriterler Tablo 2'de verilmekte olup aranan özelliklerin genel bir nitelik ile isimlendirmesi amacı için kişisel donanım, güncel takip ve teknik özellik bilgisi olmak üzere 3 ana başlık altında toplanmıştır.

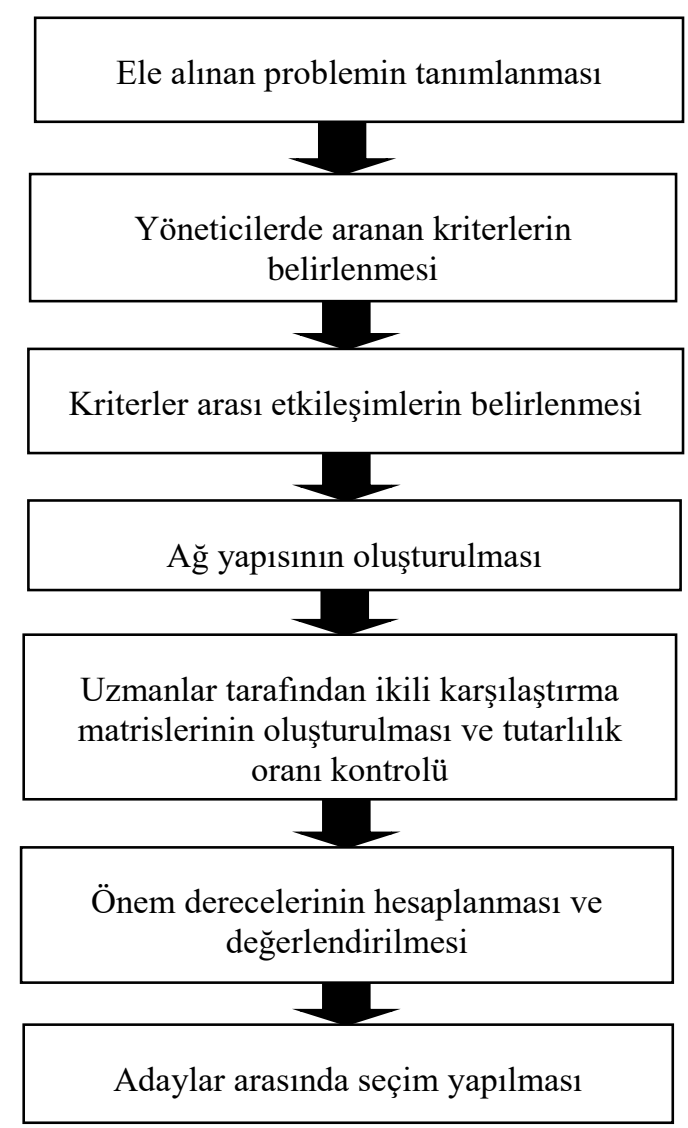

Şekil 1: Uygulama adımları

Tablo 2: Kriterler

\begin{tabular}{|c|c|}
\hline Kriter Tipi & Kriterler \\
\hline \multirow{2}{*}{ Kişisel Donanım } & Ĕ̈itim \\
\cline { 2 - 2 } & Deneyim \\
\cline { 2 - 2 } Güncel Takip & Iletişim becerisi \\
\cline { 2 - 2 } & İnternet sitesi izleme \\
\cline { 2 - 2 } & Mevzuat takibi \\
\hline \multirow{2}{*}{ Teknik Özellik Bilgisi } & Periyodik yayın takibi \\
\cline { 2 - 2 } & Bilgisayar ilgisi \\
\cline { 2 - 2 } & Muhasebe otomas bilgi sistemi \\
\hline
\end{tabular}


Kurulan ağ yapısı Şekil 2'de gösterilmiştir. Bu yap1 oluşturulurken sahadaki uygulayıcılardan ve bu konu ile ilgili akademik uzmanların görüşlerinden faydalanılmıştır.

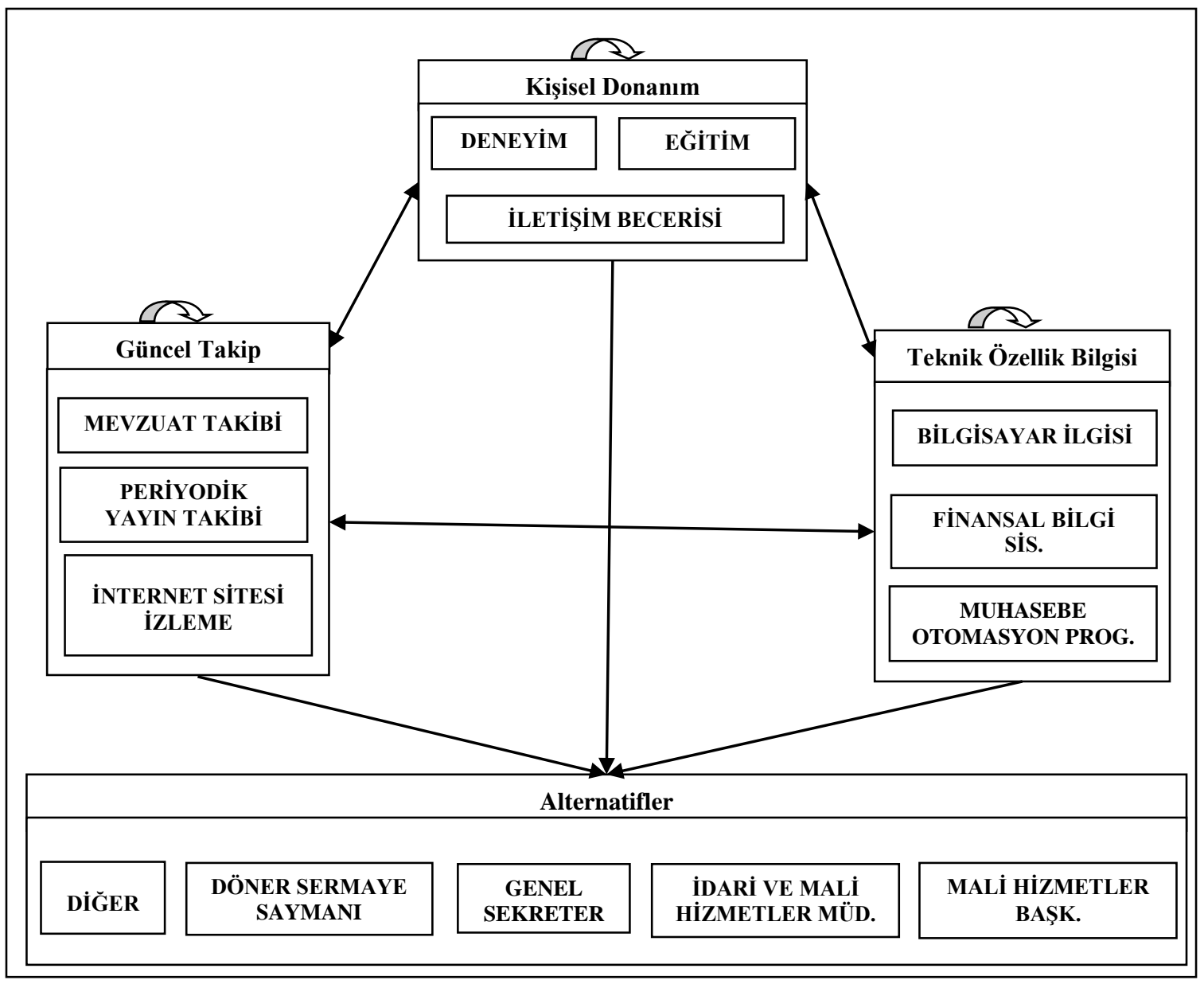

Şekil 2: A ̆g yapısı

Yönetici; başkaları vasıtasıyla iş gören kişidir. Finansal yönetici ise, işletmelerde temel finansal amaç doğrultusunda finans fonksiyonu ile ilgili organizasyonu yöneten kişi olarak ele alınır. Hastane işletmelerindeki finansal yöneticiler, işletme organizasyonu içindeki pozisyonlarına göre üç kademede incelenebilir (Akar vd., 2005:345):

Üst kademe finansal yöneticiler; hastane genel yöneticisine doğrudan bağlı olarak çalışan finansal yöneticiler olarak ele alınırlar. Finansal sistemin yönetilmesinden birinci düzeyde sorumludurlar. Kamu sahipliğindeki hastanelerde "ita amirliği”" pozisyonu üst kademe finansal yönetim pozisyonu olup hem genel/katma bütçe uygulamasında hem de döner sermaye bütçesi uygulamasında bu pozisyon genel işletme yönetimi pozisyonu ile özdeşleşmiş durumdadır. Özel sektörde "finans müdürü" olarak ifade edilir.

Orta kademe finansal yöneticiler; üst kademe finansal yöneticiye bağlı olarak çalışan finansal yöneticilerdir. Kamu sahipliğindeki hastanelerde "tahakkuk memurluğu" pozisyonu orta kademe finansal yönetici olarak adlandırılır. Kamuda yer alan sayman pozisyonları da hem gelir/gider hem de stok uygulamaları açısından orta kademe yönetici olarak tanımlanır. Özel 
sektörde ise finans müdürüne bağlı olarak çalışan, "finans müdür yardımcıları ve finansal denetçi” olarak ifade edilir.

Alt kademe finansal yöneticiler; kamu sahipliğindeki hastanelerde ita amiri, tahakkuk memuru ve sayman pozisyonları dışında kalan tüm finansal büro yöneticileri ile "ita amiri mutemedi" ve "sayman mutemetleri"nden oluşmaktadır. Hasta muhasebesi ve faturalama yöneticileri, maaş muhasebesi yöneticileri, vezneler yöneticiliği, malzeme depoları yöneticiliği, genel muhasebe yöneticiliği, maliyet muhasebesi yöneticiliği vb. büro yöneticiliklerini örnek olarak verebiliriz. Özel sektörde ise üst ve orta kademe finansal yöneticiler dışında kalan tüm finansal büro yöneticileri alt kademe finansal yönetici olarak ifade edilir.

Çalışmada ele alınan kriterler deneyim kriteri göreve alınacak kişinin daha önceki tecrübeleri, eğitim kriteri kişinin eğitim seviyesi, iletişim becerisi ise kişinin karşılarındaki kişilerle ile konuşabilme bilgilerini aktarabilme yeteneği olarak tanımlanabilmektedir. Güncel taip ana kriteri içerisindeki alt kriterler mevzuat takibi periyodik yayın takibi ve internet sitesi izleme yönetici pozisyonuna aday kişilerin güncel verileri ve bilgilere hâkim olma düzeyi, takip edebilme yeteneği olarak bilinmektedir. Teknik özellik ana kriteri içerisindeki bilgisayar ilgisi, finansal bilgi sistemleri ve muhasebe otomasyon programlarına olan bilgisi kullanabilme seviyesidir (Marriott ve Mellett, 1996: 68; Gapenski, 2005: 6; Berger, 2008:345). Hastanelerin temel finansal amaçlarına ulaşabilmesi için gerekli olan k1sa/orta/uzun vadeli planların düzenlenmesi, bütçeleme, sermaye bütçelemesi, nakit bütçelemesi vb. konularda yapılan finansal planlama faaliyetleri finans yöneticilerinin en önemli görevleri arasındadır. Bunun için pozisyonu ne olursa olsun finansal yönetim konusunda eğitim almış ve bu konuda deneyimli olmaları gereklidir. Hastane finansal yöneticilerinin kişisel ve yönetsel yeterliliklerini geliştirmek ve finansman konusunda güncel ve teknik konulardan uzak kalmamak için periyodik yayınları takip etmelidir. Günümüzün bilgi teknolojilerine ulaşmak için en önemli imkân, internet ortamında yapılan tarama ve incelemelerdir. Finansal yöneticilerin bu konuda da finansal yönetim ile ilgili olarak internet ortamından ve bilgisayardan maksimum düzeyde yararlanmalıdır. Finansal yönetimin yararlandığı temel kaynaklardan biri de mevzuat yani yasalardır. Bu pozisyonda çalışan kişilerin mevzuatı iyi bilmesi ve güncel gelişmeleri takip etmesi gereklidir. Aynı zamanda bu kişilerin, yönetsel yeterlilik açısından hastane otomasyonunu (finansal bilgi sistemi) ve muhasebe otomasyonunu bilmeleri ve veri girişi sonuçlarını yorumlayabilmeleri gereklidir. Ayrıca üst, orta ve alt finansal yönetici kademelerine bakılmaksızın, tüm finans yöneticilerinin hem kendi finansman departmanları arasında hem diğer departmanlar arasında hem de kurum dışındaki ilgili kişi ve kurumlarla sözlü ve yazılı iletişimi güçlü ve insan ilişkilerinde etkin olması gereklidir.

Kriterler arast iliskilerin belirlenmesi ve ikili karsılaștırma matrislerinin olusturulmasl: AAS yönteminin ikinci adımında oluşturulan ağ modeline göre deneyim kriteri periyodik yayın takibi, bilgisayar ilgisi, mevzuat takibi kriterleri ile karşılıklı etkileşim halinde iken; bilgisayar ilgisi kriteri finansal bilgi sistemi, muhasebe otomasyon kriteri, mevzuat takibi kriterleri ile ilişki içerisindedir. A $\breve{g}$ yapısı bu ilişkilere benzer yapılarda kurularak a ğ yapısı oluşturulmuştur. A $\breve{g}$ yapısına göre oluşturulan ikili karşılaştırma matrislerinde sahadaki uygulayıcılara ve bu konu ile ilgili akademik uzmanların görüşlerine başvurulmuştur. Toplamda 6 kişi ile görüşülerek kriterler arasında nasıl bir etkileşim olduğuna dair karşılaştırmalar yapılmıştır. Bu elde edilen karşılaş̧ırmaların geometrik ortalaması alınarak görüşler bir araya toplanmıştır. Kriterlerin önem dereceleri Saaty'nin 1-9 skalası kullanılarak belirlenmiş̧ir. Super Decision paket programı yardımıyla hesaplamalar yapılmıştır. Tablo 3'de yapılan hesaplamalar sonucu, elde edilen kriter ağırlıklarına göre gösterilmektedir. 
Tablo 3: Kriter Ăğırlıkları

\begin{tabular}{|c|c|c|}
\hline Ana kriter & Alt kriter & Kriter Ăğırlıkları \\
\hline \multirow{3}{*}{ Kişisel Donanım (0,450121) } & Deneyim & 0,42960 \\
\cline { 2 - 3 } & Eğitim & 0,41140 \\
\cline { 2 - 3 } & İletişim becerisi & 0,15900 \\
\hline \multirow{3}{*}{ Güncel Takip (0,288536) } & Mevzuat takibi & 0,34344 \\
\cline { 2 - 3 } & Periyodik yayın takibi & 0,26860 \\
\cline { 2 - 3 } & İnternet sitesi izleme & 0,38797 \\
\hline \multirow{3}{*}{ Teknik Özellik Bilgisi (0,261343) } & Bilgisayar ilgisi & 0,27350 \\
\cline { 2 - 3 } & Finansal bilgi sistemi & 0,40117 \\
\cline { 2 - 3 } & $\begin{array}{c}\text { Muhasebe otomasyon } \\
\text { programı }\end{array}$ & 0,32533 \\
\hline
\end{tabular}

Tablo 3'ten elde edilen sonuçlara göre; \%43 oranında deneyim kriteri ilk sırada yer alırken; bu sıray $\% 41$ ile eğitim kriteri, \%40 ile finansal bilgi sistemi kriteri takip etmektedir. Kriterler incelendiğinde; kişisel donanım kriterlerinden olan deneyim ve eğitim kriterinin kriter ağırlıkları yakın olmakla birlikte ilk iki sırada yer aldığı görülmektedir. Alternatif / aday sıralaması ne olursa olsun (mali hizmet başkanı, döner sermaye saymanı, genel sekreter ve idari ve mali hizmetler müdürü), bu iki kriter olmazsa olmaz kriterler arasındadır. Hastanelerin finansal yönetim ile ilgilenen görevlilerin finansal yeterlilikleri ile ilgili bir eğitim almış olmaları ve bu konuda deneyimlerinin olması şarttır. İletişim becerisi de kişisel donanım kriterleri arasında bulunmaktadır. Ancak kriter ağırlıkları incelendiğinde \%16'lik bir oranla sıralamanın sonunda yer almaktadır. Alternatiflerin / adayların sağlık kurumlarında finansal yönetim ile ilgili olması ve diğer sekiz kriterin önem derecelerinin daha baskın olması, iletişim becerisi kriterinin en sonda olmasını açıklamaktadır. Kriterlere genel olarak bakıldığında ise, kişisel donanım kriteri \%45 değer ile ilk sırada yer almaktadır. Bu da adayların deneyimi ve eğitimi seçim sürecinde önemli bir etkisi bulunmaktadır. Güncel takip kriteri ise aslında kişisel donanım açısından yeterli yetkinliğe sahip kişinin güncel bilgileri takip ederek yetkinliğini arttırması için ne kadar önemli olduğunu göstermektedir. Teknik özellik bilgisi ana kriteri içerisinde finansal bilgi sistemi ve muhasebe otomasyon programı ile ilgili alt kriterlerin ağırlığı yüksek çıksa da genel olarak bu ana kriterin diğer ana kriterler açısından ağırlığı daha azdır. Bu da hastanelere finans yöneticisi seçimi yaparken en önemli kriterin kişisel donanım kriteri olduğunu teknik özellik bilgisi kriterinin de tamamlayıcı nitelikte olduğu ve diğer kriterleri de etkilediğini göstermektedir.

Güncel takip kriterleri tablo 3'e göre değerlendirildiğinde; internet sitesi izleme \%39'luk oranla dördüncü sırada, mevzuat takibi \%34'lük oranla beşinci sırada ve muhasebe otomasyon programı ise \%33'lük oranla altıncı sırada yer almaktadır. Yedinci sırada yer alan bilgisayar ilgisi ile periyodik yayın takibi kriteri neredeyse birbirine eşittir. Mevzuat takibi, periyodik yayın takibi ya da internet sitesi izleme bir finans yöneticisinin kişisel gelişimi için önemli faktörlerden birisidir. Bu anlamda, hastanelerde finansman yönetimi konusunda güncel ve teknik konulardan uzak kalmamaları gerekmektedir. Bu nedenle güncel yayın ve mevzuat takibi hem basılı hem de internet ortamında kaçınılmaz hale gelmektedir. Aynı zamanda finansal uygulamalar mevzuatla takip edildiğinden bu konuda da finansal yöneticilerin hem mevzuat takibine hem de yayın takibine gerekli önemi vermesi gerektiğine işaret etmektedir.

Teknik özellik bilgisi kriterleri değerlendirildiğinde ise (tablo 3); finansal bilgi sistemi $\% 40$ 'lık oranla üçüncü sırada, muhasebe otomasyon program $1 \% 32$ 'lik oranla altıncı sırada ve bilgisayar ilgisi $\% 27$ 'luk oranla yedinci sırada yer almaktadır. Bu üç kriter içinden finansal bilgi 
sistemi kriter ağırlı̆̆ının üst sıralarda çıkmasının nedeni; finansal bilgi sisteminin hastane otomasyonunun odak noktası olmasından kaynaklanmaktadır. $\mathrm{Bu}$ nedenle, hastane finansal yöneticilerinin finansal bilgi sistemi ve hastane otomasyonu konusunda bilgi sahibi olması ve bilgi otomasyonu veri tabanı ile de ilgilenmesi gerekmektedir.

Kriterlerin kriter ağırlıkları incelendiğinde, birbirlerine eşit ya da çok yakın oranlarda çıktığı görülmektedir. Bu dokuz kriter bütün alternatifler / adaylar (mali hizmet başkanı, döner sermaye sayman1, genel sekreter ve idari ve mali hizmetler müdürü), için olması gereken kriterlerdendir. Hastane finansal yöneticilerinin öncelikle eğitim almış, deneyimli kişilerden olması ve buna ek olarak otomasyonu bilmesi ve mevzuata hâkim olması gerekliliği Tablo 3'teki kriter ağırlıklarına göre kriter sıralamasından da anlaşılmaktadır.

AAS yönteminde süper matrislerin oluşturulmasının ardından alternatiflerin / adayların ağıllıklarının elde edilmesi ile aday personeller arasından açılan pozisyona en uygun kişi seçilmektedir. Tablo 4’te adaylar arasındaki ağırlıklar verilmiştir.

Tablo 4: Alternatif / Aday Siralaması

\begin{tabular}{|c|c|}
\hline Alternatifler / Adaylar & Önem Dereceleri \\
\hline Mali Hizmetler Başkanı & 0,52526 \\
\hline Döner Sermaye Saymanı & 0,22340 \\
\hline Genel Sekreter / Hastane Yöneticisi & 0,12509 \\
\hline İdari ve Mali Hizmetler Müdürlüğü / Müdür Yardımcısı & 0,08965 \\
\hline Diğer (Faturalama, Maaş, Vezne, Depo vb. Büro Personeli) & 0,03659 \\
\hline
\end{tabular}

Tablo 4'e göre; alternatifler / adaylar önem derecelerine göre sıralandığında, \%53'lük oranla en uygun adayın mali hizmetler başkanı olduğu görülmektedir. Mali hizmetler başkanı, sağlık yönetimi alanında lisans ya da lisansüstü eğitim almış; nakit, alacak, stok yönetimi vb. finansal süreçlerini yönetebilen, finansal muhasebe konularına hâkim, bütçe, finansal analiz, raporlama ve finansal tablo yorumlama konularında tecrübeli, sunum yeteneğinde başarılı; mevzuatı takip edebilen, uygulama ve yorumlama becerisine sahip olan; muhasebe ve finans ile ilgili güncel yayınları takip edebilen finansal yöneticiler arasındadır. İkinci sırayı \%22'lik oranla döner sermaye saymanları almaktadır. Bu sırayı genel sekreter (\%12), idari ve mali hizmetler müdürlüğü (\%9) ve faturalama, maaş ve vezne gibi büro personeli (\%4) takip etmektedir. Hangi alternatif / aday olursa olsun hepsinin kriter önceliği tablo 3'te de belirtildiği gibi, ilgili alanlardan mezun olmak ve sağlık kurumlarında finansal yönetim konusunda deneyimli olmaktır ve ayrıca diğer belirtilen kriterleri de taşımaları gerekmektedir. Adayların her birinin üstlendikleri sorumluluklara bakıldığında ve Türkiye Kamu Hastaneleri Kurumu Taşra Teşkilatı Çalışma Usul Ve Esasları Hakkında Yönerge incelendiğinde (http://www.tkhk.gov.tr, Erişim Tarihi: 07.03.2017), sağlık kurumlarında finansal yönetim konusunda hepsinin de bu işi çok iyi derecede bilen, liyakatlı kişilerden seçilmiş olmasının gerekliliği görülmektedir.

\section{SONUÇ}

Hastaneler; ister kamu sahipliğinde olsun isterse özel hastane olsun, temel finansal amaçlarına ulaşabilmeleri için gerekli olan finansal planların düzenlenmesi, finansal örgütleme, finansal yürütme, finansal denetim, nakit yönetimi, alacak yönetimi, kaynak yönetimi, bütçeleme ve özel finansal sorunların çözümlenmesi vb. konularda yapılan finansal faaliyetler, finans yöneticilerinin en önemli görevleri arasındadır. 
$\mathrm{Bu}$ çalışmaya göre; bütün kriterleri taşımakla birlikte finansal işlerden sorumluluk düzeyinde bir sıralama yapıldığında; mali hizmetler başkanının sağlık kurumlarında finansal yönetim konusunda daha komplike bir bilgiye sahip olmasının gerekliliği sonucuna ulaşılmıştır. İta amiri konumunda genel sekreter görülmesine rağmen; genellikle hekim kökenli olup, finansal yönetim konusunda formal lisans eğitimi almadıkları ve finansal işleri daha çok mali hizmetler başkanına devrettiği için alternatif / aday sıralamasında üçüncü sırada görülmektedir.

Hastanelerde finans yöneticileri analiz edebilme yeteneğine sahip ve problemleri sistematik bir şekilde çözen kişiler olarak görülmektedir. Bu yetenekler diğer istenilen özellikleri pekiştirici nitelikte olmaktadır. Çalışma sonucuna göre \%9'luk oranla dördüncü sırada idari ve mali hizmetler müdürü yer almaktadır. Kamu hastaneleri birliğine bağlı hastaneler, hastane yöneticilerince yönetilir ve hastane finansman faaliyetleri idari ve mali hizmetler müdürlügü tarafindan yürütülmektedir. İdari ve mali hizmetler, finansal yönetim açısından değerlendirildiğinde; finansal muhasebe ve bütçe, finansal kontrol, raporlama, tedarik ve malzeme yönetimi ve stok yönetimi vb. hizmetlerin bütünüdür. İdari ve mali hizmetler müdürü; bu bölüme ait hizmetlerin planlamasının yapılması ve sunulmasını sağlamak; bütün birimlerle koordinasyonun sağlanarak hizmetin etkin ve verimli şekilde yürütülmesini planlamak; ilgili denetimlerin yapılmasını sağlamak; sağlık hizmetinin devamının sağlanması için ihtiyaç duyulan her türlü kaynağın takibini ve hazır bulundurulmasını sağlamak; sağlık tesisinde satın alma, taşınır, bakım ve onarım vb. hizmetlerin sürdürülmesini sağlamak; stok yönetiminin etkin bir şekilde yürütülmesini sağlamak; bütçeyi hazırlayıp onaya sunmak; maliyet çalışmaları ve hastane yöneticisi tarafindan verilen diğer görevleri yapmakla yükümlüdür. Böylece göreve seçilen mali hizmetler müdürü hastanenin hedeflerine yönelik stratejik planlamalar yapar ve yıllık performansını ölçerek hastanenin karlılığına katkı sağlar. Sahip olduğu yetkinlik sebebiyle hastane içi birimler arası uyumlu çalışılmasını sağlar. Ayrıca yeterli nitelikte personel istihdamını ve bu personellerin eğitimi ile ilgili çalışmalar yapar. Mali hizmetler müdürü stratejik planlarda belirlenen ilke ve hedeflere ulaşabilme sorumluluğunda olduğu için mevzuata uygunluğa göre hareket etmeli ve güncel donanım açısından yeterli seviyede olmalıdır.

Döner sermaye saymanları da en az mali hizmetler başkanı kadar sağlık kurumlarında finansal yönetim konusunda etkili ve donanımlı kişilerden olmalıdır. Çalışma sonuçlarına bakıldığında; ikinci sırada yer aldığı görülmektedir.

Pozisyonu gereği idari ve mali hizmetler müdürü, hastane yöneticisine bağlıdır ve çalışma sonuçlarına göre alternatif / aday sıralamasında dördüncü sırada yer almıştır. Sıralamanın sonunda yer alan faturalama, maaş, vezne gibi büro personeli de tüm bu dört alternatif / adayın alt birimlerinde çalışan personel olup, yaptıkları iş gereği sağlık kurumlarında finansal yönetim konusuna hâkim olmaları gerekmektedir.

Çalışma sonucuna göre; sağlık kurumları finansal yönetim konusunda önerilen adaylardan en uygun olanının kriter ağırlıkları da göz önüne alınarak finansmanla ilgili departmanlarda görevlendirilmeleri doğru bir karar olacaktır. Finansal yönetim bölümü hastanenin gelir ve gider kararları ile ilgili kararlardan sorumlu olan birimdir. Finans yöneticisin aldığı kararlar hastane ilke ve değerlerini doğrudan etkilemektedir. $\mathrm{Bu}$ yüzden seçilen finans yöneticileri hastanenin gözetecek şekilde ve aynı zamanda yönetim kararları ile çelişmeyecek şekilde stratejik kararlar almalıdır. İyi bir finans yöneticisi alınan kararların ve hazırlanan planların sistematik bir şekilde uygulanmasını sağlamak ve bu uygulama sonuçların hedefler ile ne kadar uyuş̧tuğunu kontrol etmelidir. Sağlık kurumunda finansal yönetici seçimi ile ilgili olarak yapılan bu çalışma, AAS yöntemi kullanılarak yapılan tek çalışmadır. Gelecekte yapılacak olan çalışmalar için bu kriter sayısı arttırılarak bulanık çok ölçütlü karar verme yöntemleri kullanılarak göreceli durumlar ve belirsizlik ve kesin olmayan gerçek hayat problemlerinin tanımlanması için daha kullanışlı yaklaşımlar geliştirilebilir. Bu anlamda, alanda boşluğu dolduracağı ve diğer çalışmalara da 1ş1k tutacağ düşünülmektedir. 


\section{KAYNAKÇA}

Ağırbaş, İ. (2014). Sağlık kurumlarında finansal yönetim ve maliyet analizi. Siyasal Kitabevi, Ankara.

Akar, Ç. ve Coşkun, M. (Ed.) (2002). Temel finansal kavramlar. Sağlık Kurumlarında Finansal Yönetim, Anadolu Üniversitesi Yayını No:1388, Eskişehir.

Akar, Ç., Şahin, İ., Gider, Ö. ve Akca, N. (2003). Sağllk işletmelerinde finansal yönetici yeterlilikleri. Hacettepe Üniversitesi Bilimsel Araştırmalar Birimi, Ankara.

Akar, Ç., Şahin, İ., Gider, Ö. ve Akca, N. (2005). Sağlık işletmelerinde finansal yöneticilerin yeterlilik düzeylerini geliştirme ile ilgili eğitim ihtiyaçları. Sağllk ve Hastane Yönetimi 2. Ulusal Kongresi (Uluslararası Katılımlı). "Sağlık Yönetiminde Firsatlar ve Tehditler”. Ankara Üniversitesi Sağlık Ĕ̆itim Fakültesi Sağlık Yönetimi Bölümü, Bildiriler Kitabı. 28-30 Eylül, Ankara, 334-343.

Akar, Ç., Şahin, İ., Gider, Ö. ve Akca, N. (2005). Sağlık işletmelerinde finansal yönetici yeterlilikleri. Sağlık ve Hastane Yönetimi 2. Ulusal Kongresi (Uluslararası Katılımlı). "Sağlık Yönetiminde Fırsatlar ve Tehditler". Ankara Üniversitesi Sağlık Eğitim Fakültesi Sağlık Yönetimi Bölümü, Bildiriler Kitabı. 28-30 Eylül, Ankara, 344-354.

Akar, G. S. ve Çakır, E. (2016). Lojistik sektöründe bütünleştirilmiş bulanık AHP-MOORA yaklaşımı ile personel seçimi. Yönetim Ve Ekonomi Araştırmaları Dergisi, 14(2), 185-199.

Akbulut, Y., Göktaş, B. ve Ağırbaş, İ. (Ed.) (2013). Sağllk kurumlarında finansal yönetimin kapsamı. Sağlık Kurumlarında Finansal Yönetim. Anadolu Üniversitesi Yayını No: 2863, Eskişehir.

Akca, N., Işık, O. ve Sönmez, S. (2014). Kırıkkale ilindeki sağlık kurumlarının finans ve maliyet departmanlarında çalışanların finansal bilgi düzeyleri. Sağllkta Performans ve Kalite Dergisi, 8, 121-145.

Akhlaghi, E. (2011). A rough-set based approach to design an expert system for personnel selection. World Academy of Science, Engineering and Technology, 54, 202-205.

Aktel, M., Altan, Y., Kerman, U. ve Eke, E. (2013). Türkiye'de sağlık politikalarının dönüşümü: Sağlık Bakanlığı'nın taşra örgütlenmesi üzerinden bir analiz. Sosyal Bilimler Dergisi, 15(2): 1-30.

Bedir N. ve Eren T. (2015). AHP-PROMETHEE yöntemleri entegrasyonu ile personel seçim problemi: perakende sektöründe bir uygulama. Social Sciences Research Journal, 4 (4), 46-58.

Berger, S. (2008). Fundamentals of health care financial management: A practical guide to fiscal issues and activities. John Wiley \& Sons.

Chang, K.L., Liao, S.K., Tseng, T.W., \& Liao, C.Y. (2015). An ANP based TOPSIS approach for Taiwanese service apartment location selection. Asia Pacific Management Review, 20(2), 49-55.

Chaghooshi, A. J., Janatifar, H., \& Dehghan, M. (2014). An application of AHP and similarity-based approach to personnel selection. International Journal of Business Management and Economics, 1(1), 24-32.

Cheng, E. W., Li, H., \& Yu, L. (2005). The analytic network process (ANP) approach to location selection: a shopping mall illustration. Construction Innovation, 5(2), 83-97.

Chen, C. T., Cheng, H. L., \& Hung, W. Z. (2016). A two-phase decision-making method for handling personnel selection problem. In Natural Computation, Fuzzy Systems and Knowledge Discovery (ICNC-FSKD), 12th International Conference on, August 1021-1026.

Gapenski, L. C. (2005). Healthcare finance: an introduction to accounting and financial management. Foundation of the American College of Healthcare Executives.

Gapenski Louis C. (2007). Health care finance: an introduction to accounting and financial management. AUPHA, USA.

Görgülü İ., Korkmaz M. ve Eren T. (2013). Analitik ağ prosesi ve TOPSIS yöntemleri ile optimal yatırım stratejisi seçimi. Sigma Mühendislik ve Fen Bilimleri Dergisi, 31(2), 203-213.

Gündüz, H.E. ve Banar, K. (Ed.) (2002). Sağllk kurumlarında maliyet bilgisi. Sağlık Kurumlarında Maliyet Yönetimi, Anadolu Üniversitesi Yayını No:1414, Eskişehir .

Gür, Ş., Bedir, N. ve Eren, T. (2017). Analitik ağ süreci ve PROMETHEE yöntemleri ile gıda sektöründe pazarlama stratejilerinin seçimi. Nevşehir Bilim ve Teknoloji Dergisi, 6(1), 79-92.

Hamurcu M., Gür Ş., Özder E.H. ve Eren T. (2016). A multicriteria decision making for monorail projects with analytic network process and 0-1 goal programming. International Journal of Advances in Electronics and Computer Science, 3 (7), 8-12. 
Honoré, P.A., ve Costich, J.F. (2009). Public health financial management competencies. Journal of Public Health Management and Practice, 15(4), 311-318.

İçigen, E. T. ve Çetin, E. İ. (2017). AHP temelli TOPSIS yöntemi ile konaklama işletmelerinde personel seçimi. Balkan Sosyal Bilimler Dergisi, 7(13), 179-187.

Kabak, M. (2013). A fuzzy DEMATEL-ANP based multi criteria decision making approach for personnel selection. Journal of Multiple-Valued Logic \& Soft Computing, 20(5/6), 571-593.

Kelemenis, A., \& Askounis, D. (2010). A new TOPSIS-based multi-criteria approach to personnel selection. Expert Systems with Applications, 37(7), 4999-5008.

Kenger, M. D. (2017). Banka personel seçiminin çok kriterli karar verme yöntemlerinden Entropi temelli Maut, Aras ve gri ilişskisel analiz yöntemleri ile değerlendirilmesi. Yüksek Lisans Tezi, Pamukkale Üniversitesi Sosyal Bilimler Enstitüsü, Pamukkale.

Koyuncu, O. ve Özcan, M. (2014). Personel seçim sürecinde analitik hiyerarşi süreci ve TOPSIS yöntemlerinin karşılaştırılması: otomotiv sektöründe bir uygulama. Hacettepe Üniversitesi İktisadi ve İdari Bilimler Fakültesi Dergisi, 32(2), 195-218

Lin, H.T. (2010). Personnel selection using analytic network process and fuzzy data envelopment analysis approaches. Computers \& Industrial Engineering, 59(4), 937-944.

Marriott, N., \& Mellett, H. (1996). Health care managers' financial skills: measurement, analysis and implications. Accounting Education, 5(1), 61-74.

Meade, L. M., \& Presley, A. (2002). R\&D project selection using the analytic network process. IEEE Transactions on Engineering Management, 49(1), 59-66.

Mojaheed, M., Marjani, M.E., Afshari, A.R., \& Marjani, S. (2013). Using ELECTRE-AHP as a mixed method for personnel selection. In Proceedings of The International Symposium on The Analytic Hierarchy Process, 1-11.

Özbek A. ve Eren T. (2013). Analitik ağ süreci yaklaşımıyla üçüncü parti lojistik (3PL) firma seçimi. Atatürk Üniversitesi İ.I.B.F. Dergisi, 27 (1), 95-113.

Özcan, E.C., Özcan, N.A. ve Eren, T. (2017). CSP teknolojisine sahip güneş enerjisi santrallarının kombine ANPPROMETHEE yaklaşımı ile seçimi. Başkent Üniversitesi, Ticari Bilimler Fakültesi Dergisi, 1 (1), 18-44, 2017.

Özder, E., Gür Ş. ve Eren T. (2016, October). İşletmelerde muhasebeci seçimi için analitik hiyerarşi yönteminin kullanılması. The 13th International Accounting Conference, İzmir, Turkey.

Özder, E., Gür Ş. ve Eren T. (2016, October). İşletmelerde yönetimin etkinliğini arttırmak için ANP ve TOPSIS yöntemleri ile muhasebe paket programı seçimi. The 13th International Accounting Conference, İzmir, Turkey.

Özgülbaş, N. (1995). Hastanelerde finansal yönetim: sorunlar ve çözüm önerileri. Sağlık Kurumları Yönetimi Programı Bilim Uzmanlığı Tezi, Hacettepe Üniversitesi, Sağlık Bilimleri Enstitüsü, Ankara.

Özgülbaş, N. ve Coşkun, M. (Ed.) (2002). Sağlık kurumlarında finansal planlama. Sağlık Kurumlarında Finansal Yönetim, Anadolu Üniversitesi Yayını No:1388, Eskişehir.

Özgülbaş N. ve Top, M. (Ed.) (2013). Maliyet muhasebesi ve temel maliyet kavramları. Sağlık Kurumlarında Maliyet Yönetimi. Anadolu Üniversitesi Yayını No:2865, Eskişehir.

Pamukçu, H. (2014). Turizm sektöründe teşvik veren kurumların AHP ve ANP yöntemi ile belirlenmesi: Kastamonu örneği. Yüksek Lisans Tezi, Afyon Kocatepe Üniversitesi Sosyal Bilimler Enstitüsü, Afyon.

Saad, R.M., Ahmad, M.Z., Abu, M.S., \& Jusoh, M.S. (2013). Some fuzzy techniques for staff selection process: a survey. In Proceedings of the 20th National Symposium on Mathematical Sciences, April 462-469.

Saaty, T. L. (1990). How to make a decision: the analytic hierarchy process. European journal of operational research, 48(1), 9-26.

Şah, N. (2010). Analitik serim süreci yöntemi ile Mersin-Torino arasındaki güzergâh alternatiflerinin değerlendirilmesi. Yüksek Lisans Tezi, Dokuz Eylül Üniversitesi Sosyal Bilimler Enstitüsü, İzmir.

Türkiye Kamu Hastaneleri Kurumu Taşra Teşkilatı Çalışma Usul ve Esasları Hakkında Yönerge; http://www.tkhk.gov.tr/Dosyalar/ab300b9921404be48d285c696753e067.pdf (Erişim Tarihi: 07.03.2017).

Ulutaş, A., Özkan, A. M. ve Tağraf, H. (2018). Bulanık analitik hiyerarşi süreci ve bulanık gri ilişkisel analizi yöntemleri kullanılarak personel seçimi yapılması. Elektronik Sosyal Bilimler Dergisi, 17(65), 223-232. 
Yıldız, M. S. ve Aksoy, S. (2015). Analitik hiyerarşi prosesi ile personel seçimi üzerine bir çalışma. Abant İzzet Baysal Üniversitesi Sosyal Bilimler Enstitüsü Dergisi, 15(1), 59-83.

Zolfani, S.H., \& Banihashemi, S.S.A. (2014). Personnel selection based on a novel model of game theory and MCDM approaches. In Proc. of 8th International Scientific Conference, May, Business and Management, 15-16. 